\title{
Region-specific expression of androgen and growth factor pathway genes in the rat epididymis and the effects of dual $5 \alpha$-reductase inhibition
}

\author{
Natali Anne Henderson ${ }^{1}$, Gerard M Cooke ${ }^{3,4}$ and Bernard Robaire ${ }^{1,2}$ \\ Departments of ${ }^{1}$ Pharmacology and Therapeutics, ${ }^{2}$ Obstetrics and Gynecology, McGill University, 3655 Promenade Sir-William-Osler, Montréal, Québec, \\ Canada H3G 1 Y 6 \\ ${ }^{3}$ Toxicology Research Division, Health Products and Foods Branch, Food Directorate, Health Canada, Ottawa, Ontario, Canada \\ ${ }^{4}$ Reproductive Biology Unit, Departments of Cellular and Molecular Medicine and Obstetrics and Gynecology, University of Ottawa, Sir Frederick G Banting \\ Research Centre, 2202D1 Tunney's Pasture, Ottawa, Ontario, Canada K1A OL2
}

(Requests for offprints should be addressed to B Robaire; Email: bernard.robaire@mcgill.ca)

\begin{abstract}
Dihydrotestosterone (DHT) is the primary androgen acting in the epididymis, the site of sperm maturation. Previously, we showed that the treatment of male rats with PNU157706, an inhibitor that acts on both isoforms of $5 \alpha$-reductase to prevent DHT formation, has effects on the expression of genes implicated in processes that create the optimal luminal microenvironment required for sperm maturation, and on sperm maturation itself. However, signaling pathways involved in regulating or mediating DHT actions in the epididymis remain largely unknown. The goals of this study were to determine the expression profiles of potential signaling systems in the epididymis and assess their DHTdependence using two different dual $5 \alpha$-reductase inhibitors. Rats were untreated or gavaged with vehicle, $10 \mathrm{mg} / \mathrm{kg}$ per day PNU157706 or $32 \mathrm{mg} / \mathrm{kg}$ per day FK143 for 28 days and epididymal gene expression was analyzed. Gene array analysis
\end{abstract}

revealed analogous effects of FK143 on overall epididymal gene expression when compared with previous PNU157706 studies. Quantitative RT-PCR analysis of the expression of the $5 \alpha$-reductase isozymes, androgen receptor, and members of the IGF, FGF, TGF, and VEGF families revealed novel region-specific expression profiles in the epididymis that were differentially affected by $5 \alpha$-reductase inhibition; the two inhibitors had parallel effects. Specifically, in proximal regions, $5 \alpha$-reductase 1 , androgen receptor, and TGF- $\beta 1$ expression increased after treatment, while in distal regions expression of IGF-I, IGFBP-5, IGFBP-6, and FGF-10 decreased. These results provide insight into epididymal signaling mechanisms and indicate potential candidates acting either upstream or downstream of DHT to regulate and/or mediate its actions in the epididymis.

Journal of Endocrinology (2006) 190, 779-791

\section{Introduction}

The epididymis is a highly specialized tissue within the male excurrent duct system that functions in the transport, maturation, protection, and storage of spermatozoa (Orgebin-Crist 1967, Robaire \& Hinton 2002). The four distinct regions of the epididymis that carry out the sperm-related functions are: the initial segment, caput, corpus and cauda epididymidis. Importantly, the acquisition of progressive motility and fertilizing ability (i.e. sperm maturation) requires the successive exposure of spermatozoa to the particular luminal environment created by different epididymal regions (Orgebin-Crist 1967, Robaire \& Hinton 2002). The functional segmentation of the epididymis is reflected at the molecular level by complex region-specific gene expression profiles (Jervis \& Robaire 2001, Cornwall et al. 2002). The unique patterns of gene expression along the duct contribute to the evolving repertoire of components that make up the highly specialized luminal fluid.
The structure and functions of the epididymis are highly dependent on androgens (Blaquier et al. 1972, Orgebin-Crist \& Tichenor 1973). More specifically, several studies have clearly shown that the primary androgen acting in this tissue is dihydrotestosterone (DHT) (Gloyna \& Wilson 1969, Tindall et al. 1972, Orgebin-Crist et al. 1976, Turner et al. 1984). $5 \alpha$-Reductase (EC 1.3.1.22) is the enzyme that catalyzes the conversion of testosterone to DHT. Both the isoforms of $5 \alpha$-reductase (type- 1 and type-2) are present in the epididymis and are differentially expressed along the tubule (Viger \& Robaire 1996).

Previously, using gene expression profiling, we have shown that the treatment of adult male rats with the dual $5 \alpha$-reductase inhibitor, PNU157706, has a highly regionspecific effect on epididymal gene expression (Henderson et al. 2004). The affected genes are involved in fatty acid and lipid metabolism, regulation of ion and fluid transport, luminal acidification, oxidative defense, and protein 
processing and degradation; these are essential processes that contribute to the formation of the optimal luminal microenvironment (Henderson et al. 2004).

Importantly, distinctive region-specific epididymal gene expression changes also occur during aging and in response to other experimental manipulations, such as orchidectomy, caloric restriction, and vitamin $\mathrm{E}$ treatments (Jervis \& Robaire 2002, 2003, 2004, Ezer \& Robaire 2003). These responses clearly demonstrate the differential regulation of this tissue, however, surprisingly, little is known about how this regulation is achieved. While DHT clearly has a prominent role in the epididymis, the involvement of other signaling molecules and pathways, for example, growth factor systems that have been recently characterized in other reproductive tissues (Culig et al. 1994, 1995, Gnessi et al. 1997, Orio et al. 2002, Huang et al. 2004), remains to be deciphered. Therefore, the main objective of the present study was to examine the effects of $5 \alpha$-reductase inhibition on the expression of potential signaling systems in the epididymis, in order to elucidate possible mechanisms of DHT action in this tissue.

In the present study, gene arrays were used to analyze the effects of a second $5 \alpha$-reductase inhibitor, FK143, on gene expression; FK143 is a non-steroidal, non-competitive inhibitor of both the isozymes of $5 \alpha$-reductase (Hirosumi et al. 1995a,b). The cumulative array data from this study and our previous PNU157706 study (Henderson et al. 2004), as well as the present literature, were used as a guide in the selection of genes potentially involved in epididymal regulatory mechanisms for further characterization in the epididymis. The genes chosen include, both the isozymes of $5 \alpha$-reductase and the androgen receptor, which are directly involved in mediating androgen action in the epididymis, as well as those involved in different growth factor signaling systems. Interestingly, there is recent evidence supporting a role for various growth factors in epididymal function; for example, the overexpression of VEGF in the testis and epididymis of transgenic mice results in infertility (Korpelainen et al. 1998). In a different animal model, the GH-deficient dwarf $(d w / d w)$ rat, the administration of insulin-like growth factor-I increases the motility and improves the morphology of immature spermatozoa (Vickers et al. 1999). Whether an epididymal mechanism contributes completely or in part to the effects of these growth factors in such animal models has not yet been determined, but it is certainly possible that these and other growth factor systems are involved in epididymal regulation.

The steady-state epididymal expression profiles of the selected genes were analyzed using the sensitive technique of quantitative real-time RT-PCR. We then assessed the effects of both $5 \alpha$-reductase inhibitors (PNU157706 and FK143) on the epididymal expression of these androgen and growth factor-signaling genes to determine whether they are dependent on DHT, and thus potentially acting as upstream (i.e. the $5 \alpha$-reductase isozymes) or downstream regulators of DHT-dependent gene expression and function.

\section{Materials and Methods}

\section{Animals}

Adult male Sprague-Dawley rats (325-350 g) were obtained from Charles River Canada (St Constant, PQ, Canada), maintained under controlled light (14 h light:10 h darkness) and temperature $\left(22^{\circ} \mathrm{C}\right)$, and provided with food and water ad libitum. The caput-corpus epididymides from 90-day-old animals that were previously stored at $-80{ }^{\circ} \mathrm{C}$ were used for in vitro enzyme assays. For in vivo studies, adult male rats were left untreated (for determination of steady-state mRNA profiles, $n=5$ ) or were randomly divided into three treatment groups $(n=5)$ and gavaged with $0.5 \mathrm{ml} / \mathrm{kg}$ of either the vehicle alone (control group) or $10 \mathrm{mg} / \mathrm{kg}$ PNU157706 or $32 \mathrm{mg} / \mathrm{kg}$ FK143 (inhibitor treatment groups) suspended in vehicle $(0.5 \%$ methylcellulose solution $(\mathrm{BDH}$, Montréal, QC, Canada) containing 0.4\% Tween 80 (A\&C American Chemicals Ltd, Montreal, QC, Canada)) for 28 consecutive days. Doses were selected based on reported effects on rat ventral prostate; the dosing regimen with $10 \mathrm{mg} / \mathrm{kg}$ per day PNU157706 or $32 \mathrm{mg} / \mathrm{kg}$ per day FK143 has been shown to decrease prostatic dihydrotestosterone levels by $>90 \%$ (Hirosumi et al. 1995a,b, di Salle et al. 1998). Epididymides from untreated and treated rats were sectioned into initial segment, caput, corpus, and cauda epididymides and immediately frozen in liquid nitrogen. The tissues were stored at $-80^{\circ} \mathrm{C}$ until used for RNA extraction. The changes in reproductive tissue weights with treatment were consistent with what has been reported previously for both compounds (Hirosumi et al. 1995a,b, di Salle et al. 1998, Henderson et al. 2004). All animal studies were conducted in accordance with the principles and procedures outlined in the Guide to the Care and Use of Experimental Animals prepared by the Canadian Council on Animal Care (McGill Animal care Committee protocol no. 206).

\section{In vitro $5 \alpha$-reductase assays}

Unlabeled steroids were purchased from Steraloids, Inc., (Newport, RI, USA); $\left(1,2,6,7-{ }^{3} \mathrm{H}\right)$ testosterone $(74 \cdot 0 \mathrm{Ci} / \mathrm{mmol})$ from Dupont/NEN (Boston, MA, USA); organic solvents from BDH; dimethylglutaric acid (DMG), NADPH, and dimethyl sulfoxide (DMSO) from Sigma and plastic-coated Whatman PE SIL G silica gel chromatography plates from Chromatographic Specialties (Montréal, QC, Canada). FK143 solutions were prepared in DMSO.

Frozen caput-corpus epididymides (only control, untreated tissues were used) were thawed, homogenized (Polytron) in DMG buffer (50 mM DMG, $5 \%$ glycerol, $\mathrm{NaOH}$, and $0.5 \mathrm{mM}$ $\mathrm{NADPH}) \mathrm{pH} 6 \cdot 5$, and the nuclear and microsomal fractions were assayed for $5 \alpha$-reductase activity as previously described for PNU157706 (Henderson et al. 2004). Briefly, kinetic studies of $5 \alpha$-reductase activity were done at $\mathrm{pH} 6.5$ with testosterone (nine concentrations ranging from 5 to $375 \mathrm{nM}$ ). To determine the effects of FK143 on $5 \alpha$-reductase activity, FK143 was 
included at concentrations of $0,3,15$, and $45 \mathrm{nM}$. A single incubation time of $1 \mathrm{~h}$ and an incubation volume $1 \mathrm{ml}$ were used in kinetic studies. To obtain the apparent Michaelis constant $\left(K_{\mathrm{m}(\text { app })}\right)$ and apparent maximum velocity $\left(V_{\max (\text { app })}\right)$, the Wilkinson method (non-linear least squares analysis of a rectangular hyperbola) was used (Wilkinson 1961). Slope and intercept replots were obtained by the formula, $K_{\mathrm{m}(\mathrm{app})} /$ $V_{\max (\text { app) }}$ vs [I], and $1 / V_{\max (a p p)}$ vs [I] respectively. Linear regression analysis of the replots was employed to determine the $K_{\mathrm{i}(\text { app })}$ values.

\section{RNA extraction}

From each sample, the total RNA was extracted using the RNeasy extraction kit with DNase1 treatment (Qiagen) according to the manufacturer's protocol, with the exception that the on-column DNase digestion was extended to $1 \mathrm{~h}$. RNA concentration was assessed by optical density determination at $260 \mathrm{~nm}$ (Beckman DU7 spectrophotometer, Montréal, PQ, Canada). In addition to spectrophotometric reading, RNA quality was verified by conventional gel electrophoresis. Each sample consisted of a single epididymal region obtained from individual rats, i.e. no tissues were pooled.

\section{cDNA arrays and hybridization}

The effects of FK143 treatment on epididymal gene expression were analyzed with cDNA arrays as described previously (Henderson et al. 2004). Briefly, RNA samples were used to probe cDNA arrays (BD Biosciences Atlas Rat $1 \cdot 2 \mathrm{~K}$ array) according to the manufacturer's instructions. Four arrays per epididymal region per treatment group (control, FK143) were probed and referred as replicates $(n=4 /$ treatment per region). Arrays were exposed to phosphorimager plates (Molecular Dynamics, Sunnyvale, CA, USA) $24 \mathrm{~h}$ before scanning with a phosphorimager (Storm, Molecular Dynamics). Analysis of array images with Atlas Image (Version 2.0, BD Biosciences) was done to quantify the intensity of each cDNA spot, which reflects the relative abundance of RNA in the sample. The raw data for each gene (intensity minus the background) were imported into GeneSpring 4.0.7 (Silicon Genetics, Redwood, CA, USA) for further analysis. For each replicate array in a given treatment group, a gene was considered detected if its intensity was above threshold, which is defined as two times the average background of that individual array. A gene was considered expressed if it was detected in at least three replicates in that group.

To minimize experimental variation and allow comparison of different treatment groups, data were normalized with the standard experiment-to-experiment normalization (GeneSpring). Specifically, the median level of expression on each array was defined as 1 and expression of each gene was normalized relative to 1 . This value was averaged for all replicates in a group to generate what is referred to as the relative intensity for a given gene. A transcript was considered differentially expressed if the change in relative intensity between the control and the treatment group was twofold or greater (i.e. $50 \%$ decrease or $100 \%$ increase). The importance of replication for validation of gene-expression studies has been documented (Lee et al. 2000, Herwig et al. 2001).

\section{Quantitative real-time RT-PCR}

The expression of selected genes (Table 1) was analyzed by quantitative real-time RT-PCR. Analysis of the steady-state expression profiles for the selected genes along the epididymis was done using RNA samples extracted from the epididymides of untreated adult rats $(n=4-5)$. Analysis of the effects of $5 \alpha$-reductase inhibition on the epididymal expression profiles of selected genes was done using RNA samples extracted from the epididymides of vehicle, PNU157706and FK143-treated rats $(n=4-5)$. As expected, the steadystate (untreated) and vehicle-treated expression profiles for all

Table 1 Details of primers used in quantitative real-time RT-PCR experiments

\begin{tabular}{|c|c|c|c|c|}
\hline & Accession no. & Forward primer & Reverse primer & Reference \\
\hline \multicolumn{5}{|l|}{ Gene } \\
\hline $5 \alpha-R 1$ & NM_017070 & CGTCCTGCTGGCTATGTTTC & GAAGGCCAAGACAAAGGTGA & $\mathrm{NA}$ \\
\hline $5 \alpha-R 2$ & NM_022711 & GGACССTGATCCTGTGCTTA & ACACCACAAAGGAAGGCAAC & $\mathrm{NA}$ \\
\hline AR & NM_012502 & CTAGCGCGTGCCTTCCTTTACA & СССАCСTGCGGGAAGCT & Turner et al. (2003) \\
\hline IGF-1 & NM_178866 & CACAGGCTATGGCTCCAGCAT & TCTCCAGCCTCCTCAGATCACA & Turner et al. (2003) \\
\hline IGF-1R & NM_052807 & CGCTGTGTGGACCGGGATTT & GCATGCACTCGCCATCGTG & Turner et al. (2003) \\
\hline IGFBP-5 & NM_012817 & GTGACCGCAAAGGATTCTACAAGA & GGCAGCTTCATCCCATACTTGTC & Turner et al. (2003) \\
\hline IGFBP-6 & NM_013104 & ACСТCGGCTGССССТATAAGG & TCAGTCTGGAGCTGCTGCAGTAC & Turner et al. (2003) \\
\hline FGF-10 & NM_012951 & GCTGCTGTTGCTGCTTCTTGTTG & GCTGCTGTTGCTGCTTCTTGTTG & Turner et al. (2003) \\
\hline FGFR-2 & XM_341940 & TTCCCCAGATTACCTGGAGATAGC & TCGTGGTCTTCATTCGGCAA & Turner et al. (2003) \\
\hline TGF- $\beta 1$ & NM_021578 & GTTCTTCAATACGTCAGACATTCG & САTTATCTTTGCTGTCACAAGAGC & Hanawa et al. (2002 \\
\hline TGF- $\beta 1 R$ & NM_012775 & AATGTTACGCCATGAAAATATCCT & TACAACAGGTTCCATTTTTCTTCA & Hanawa et al. (2002 \\
\hline VEGF & NM_031836 & CAGCTATTGCCGTCCAATTGA & CCAGGGCTTCATCATTGCA & Gomez et al. (2003) \\
\hline VEGFR-2 & NM_013062 & TCAGAGACACTGAGCATGGAA & GTTTTCAGCTCTTCTGAGGCAA & Gomez et al. (2003) \\
\hline Cyclophilin & NM_008907 & ACACGCCATAATGGCACTGG & ATTTGCCATGGACAAGATGCC & Cupp et al. (1999) \\
\hline
\end{tabular}

NA, not applicable. Accession numbers are for the Genbank database. 
the genes examined were indistinguishable. For simplicity, only the vehicle-treated profiles are shown, which are representative of the steady-state expression profiles, discussed in the Results section.

First-strand cDNA (cDNA) was synthesized from $1 \mu \mathrm{g}$ total RNA using SuperScript-II reverse transcriptase (Invitrogen-Life Technologies, Carlsbad, CA, USA) and oligo $\mathrm{dT}_{(12-18)}$ primers (Invitrogen-Life Technologies) according to the manufacturer's instructions, with the exception that only half the concentration of DTT was used (Lekanne Deprez et al. 2002). The reverse transcription (RT) reactions were then diluted in a ratio of $1: 3$ and $1 \mu \mathrm{l}$ aliquots of the diluted $\mathrm{RT}$ samples were used for subsequent quantitative real-time PCR analysis.

Quantitative real-time PCR was carried out on the LightCycler system (Roche) using the Quantitect SYBR green PCR kit (Qiagen) according to the manufacturer's protocol. The gene-specific primer sequences (Table 1) were obtained from the literature or designed using Primer3 software (http://frodo. wi.mit.edu/cgi-bin/primer3/primer3.cgi/). Briefly, each PCR contained $1 \mu \mathrm{l}$ cDNA (RT sample), $0.5 \mu \mathrm{M}$ genespecific primers, and $10 \mu \mathrm{l}$ SYBR green master mix. The PCR cycling conditions were as follows: initial denaturation/enzyme activation for $15 \mathrm{~min}$ at $95^{\circ} \mathrm{C}$ followed by $40-60$ cycles of denaturation at $95^{\circ} \mathrm{C}$ for $10 \mathrm{~s}$, annealing at $57-60{ }^{\circ} \mathrm{C}$ for $5 \mathrm{~s}$ and elongation at $72{ }^{\circ} \mathrm{C}$ for $10 \mathrm{~s}$. The production of a single PCR product was confirmed by melting-curve analysis and conventional gel electrophoresis.

The relative quantification of mRNA was done according to the standard curve method (refer to Applied Biosystems User Bulletin no. 2, reviewed in Bustin 2002). The same RT sample was used to assay each target gene and the reference gene cyclophilin in separate (LightCycler) PCR runs. Cyclophilin was chosen as the endogenous control because of its invariant expression throughout the epididymis and lack of response to androgen status (Palladino \& Hinton 1994). A stock of standard curve cDNA was made as follows: total RNA was extracted from the four epididymal regions (initial segment, caput, corpus, and cauda epididymides) of an untreated adult rat, then equal amounts of RNA from each region were mixed together to create a standard $1 \mu \mathrm{g} / \mu \mathrm{l}$ RNA solution. Subsequently, several $1 \mu 1$ aliquots of RNA standard were reverse-transcribed into cDNA as described previously and then pooled together to create a standard cDNA stock that was used in all PCR experiments. For each analysis, six serial dilutions of the standard cDNA were run as a calibration curve parallel to the samples. The levels of mRNA for each gene (target and reference genes) were determined by comparing each sample to the appropriate standard curve. All standards and samples were assayed in duplicate. Average values for the target gene RNA concentrations determined from each RT sample preparation were normalized to the average value for cyclophilin RNA concentration determined from the same RT sample preparation.

\section{Statistical analysis}

For the steady-state real-time PCR gene expression profiles, differences between epididymal regions were analyzed by ANOVA followed by Tukey's test. To analyze the differences in gene expression between the vehicle (control) and the inhibitor treatment groups, ANOVA followed by Dunnett's test was done. The level of significance was set at $P \leq 0 \cdot 05$ for all analyses.

\section{Results}

\section{Effect of FK143 on epididymal $5 \alpha$-reductase activity}

The inhibitory effect of FK143 on $5 \alpha$-reductase was assessed in vitro by examining the effects of FK143 on $5 \alpha$-reductase activity of nuclear and microsomal epididymal fractions. The addition of FK143 to incubations at concentrations $0,3,15$, and $45 \mathrm{nM}$ inhibited epididymal $5 \alpha$-reductase as shown in Fig. 1A (nuclear fraction) and B (microsomal fraction). Kinetic analyses demonstrated that FK143 caused the $V_{\max (a p p)}$ values to decrease (by about $75 \%$ ) with no consistent effect on the $K_{\mathrm{m}(\mathrm{app})}$ values. Confirmation of these findings was achieved with slope $\left(K_{\mathrm{m}(\mathrm{app})} / V_{\max (\text { app })}\right.$ vs [I]) and intercept $\left(1 / V_{\max (a p p)}\right.$ vs $\left.[\mathrm{I}]\right)$ replots, shown in Fig. 1C (nuclear) and D (microsomal); the slopes of the slope replots were negative or almost horizontal, whereas the slopes of the intercept replots were positive. The values for the inhibition constant $\left(K_{\mathrm{i}(\mathrm{app})}\right)$ for FK143 determined from the slope and intercept replots were $56 \cdot 6$ and $26 \cdot 5$ for the nuclear $5 \alpha$-reductase fraction and $44 \cdot 5$ and $53 \cdot 4$ for the microsomal $5 \alpha$-reductase fraction respectively. Since, the $K_{\mathrm{i}(\mathrm{app})}$ values from both slope and intercept replots were almost identical, it was clear that the $K_{\mathrm{m}(\mathrm{app})}$ did not influence the $K_{\mathrm{i}(\mathrm{app})}$ values determined; these findings were consistent with FK143 being a non-competitive inhibitor of $5 \alpha$-reductase, as has been reported for other tissues (Hirosumi et al. 1995a,b).

\section{Effects of FK143 on epididymal gene expression}

Comparison of the gene array data from the present FK143 study to our previous study using PNU157706 (Henderson et al. 2004) revealed analogous effects of different inhibitors on epididymal gene expression; both the nature of the affected genes and the direction of expression changes (i.e. increased or decreased expression) were very similar. In the present study, the expression of a greater number of genes met our detection analysis criteria (i.e. were detectable above the set background expression threshold) therefore, a greater number of genes were analyzed. Novel changes in gene expression (twofold minimum) that were revealed in the present gene array study are reported in Table 2 .

The comparison of the effects of two different inhibitors added greater power to our analyses such that we could identify genes with expression changes that were less than twofold, but consistently affected by treatment with both inhibitors. 
A

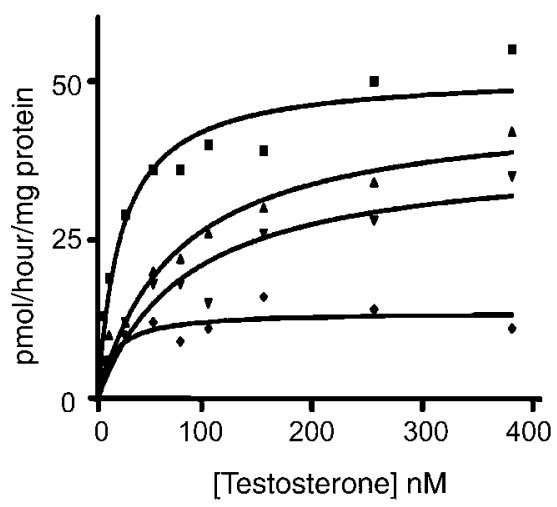

C

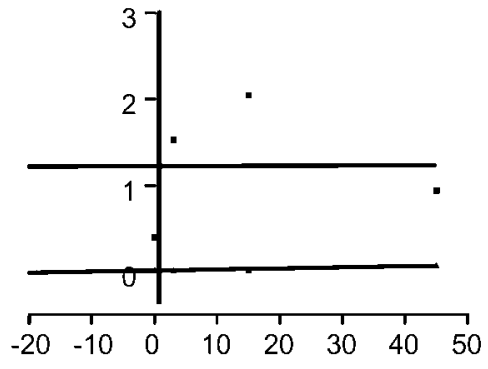

[FK 143] nM
B
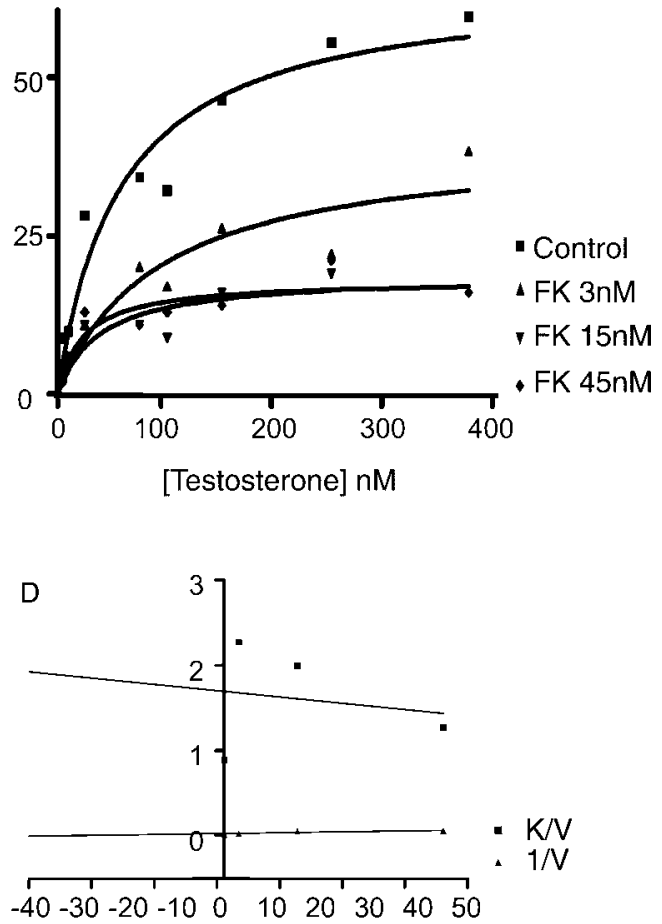

[FK 143] nM

Figure 1 Inhibition of rat nuclear (A) and microsomal (B) $5 \alpha$-reductase activity in vitro by different concentrations of FK143 (FK). For nuclear (C) and microsomal (D) $5 \alpha$-reductase, slope replots (squares) were obtained from $K_{\mathrm{m}(\text { app })} / V_{\max (\mathrm{app})} \mathrm{vs}$ (FK) and intercept replots (triangles) from $1 / V_{\max (\mathrm{app})} \mathrm{vs}$ (FK).

Among these genes was $5 \alpha$-reductase type-2, which is of particular relevance to the present study as it is one of the isozymes that catalyzes the formation of DHT; the averaged response of this gene to $5 \alpha$-reductase inhibitor treatment (determined from the array studies) was $1 \cdot 4-, 1 \cdot 6-$, and $1 \cdot 8$ fold decreased expression in the initial segment, caput, and corpus epididymides respectively. Also, among these genes were several insulin-like growth factor (IGF) family members. For example, following inhibitor treatment, the expression of IGF-binding protein-5 (IGFBP-5) decreased by an average of $1 \cdot 1-, 1 \cdot 4-$, and $1 \cdot 5$-fold in the caput, corpus, and cauda epididymides respectively, and IGFBP-6 expression increased by an average of $1 \cdot 1$-fold in the initial segment and decreased by $1 \cdot 4$-fold in the corpus epididymidis. Lastly, the expression of IGF-I and IGF-I receptor (IGF-IR) decreased by an average of $1 \cdot 4-$ and $1 \cdot 6$-fold respectively, in the cauda epididymidis following $5 \alpha$-reductase inhibitor treatment.

In accordance with the main objective of this study to identify potential signaling systems involved in epididymal regulation, we undertook to characterize the expression of the above-mentioned genes as well as other mediators of androgen action ( $5 \alpha$-reductase type-1, androgen receptor) and other growth factor family members (chosen based on the current literature) using more sensitive technique of quantitative real-time RT-PCR.
Expression of $5 \alpha$-reductases and the androgen receptor in the epididymis

We examined the steady-state expression levels of $5 \alpha$-reductase types- 1 and 2 and the androgen receptor in the epididymis using real-time RT-PCR (Fig. 2, black bars). These three genes have been previously characterized in the epididymidis by northern blot analysis (Viger \& Robaire 1995, 1996). The gene expression results obtained using these two techniques were analogous for all the three genes. $5 \alpha$-Reductase type- 1 was expressed in the initial segment at levels approximately fourfold higher than the other regions of the epididymis. $5 \alpha$-Reductase type- 2 was also highly expressed in the initial segment, peaked slightly in the caput epididymidis, and decreased in the corpus and cauda epididymides. Androgen receptor gene expression was relatively constant throughout the epididymis.

Dual $5 \alpha$-reductase inhibitor treatment had differential effects on the expression of $5 \alpha$-reductase types 1 and 2 and the androgen receptor in the epididymis (Fig. 2). Both compounds had similar effects on the different geneexpression profiles. $5 \alpha$-Reductase type- 1 expression was uniquely affected in the initial segment where it increased maximally with FK143 treatment by nearly twofold. Androgen receptor gene expression also increased following 
Table 2 Genes that showed a minimum twofold change in expression uniquely in one epididymal region following FK143 treatment

\section{Fold-change in expression}

\begin{tabular}{|c|c|c|c|}
\hline $\mathrm{FK}^{\mathrm{a}}$ & $\mathrm{PNU}^{\mathrm{b}}$ & Acc. number & Functional classification \\
\hline$\downarrow 2 \cdot 7$ & $\downarrow 1 \cdot 4$ & M14050 & Chaperones and heat shock proteins \\
\hline$\uparrow 2 \cdot 9$ & $\uparrow 1 \cdot 5$ & M61219 & $\begin{array}{l}\text { Intracellular adaptors and receptor-associated } \\
\text { proteins }\end{array}$ \\
\hline$\uparrow 2 \cdot 8$ & $\uparrow 1 \cdot 1$ & D13126 & Calcium-binding proteins \\
\hline$\uparrow 2 \cdot 3$ & $\uparrow 1 \cdot 1$ & V01217 & Cytoskeleton and motility proteins \\
\hline$\uparrow 2 \cdot 3$ & $\uparrow 1 \cdot 2$ & Z11932 & Hormone/G protein-coupled receptors \\
\hline$\uparrow 2 \cdot 2$ & $\uparrow 1 \cdot 1$ & D14592 & Intracellular kinase network members \\
\hline$\uparrow 2 \cdot 2$ & $\uparrow 1 \cdot 1$ & L15619 & Intracellular kinase network members \\
\hline$\uparrow 2 \cdot 2$ & $\uparrow 1 \cdot 0$ & K03502 & Translation factors \\
\hline$\uparrow 2 \cdot 1$ & $\uparrow 1 \cdot 1$ & U61696 & Metalloproteinases \\
\hline$\uparrow 2 \cdot 1$ & $\uparrow 1 \cdot 5$ & U62326 & Growth factors, cytokines and chemokines \\
\hline$\uparrow 2 \cdot 0$ & $\uparrow 1 \cdot 5$ & Y00697 & Cysteine proteases \\
\hline$\uparrow 2 \cdot 0$ & $\uparrow 1 \cdot 3$ & X62908 & Other cytoskeleton and motility proteins \\
\hline$\downarrow 4 \cdot 5$ & $\downarrow 1 \cdot 8$ & L08831 & Other extracellular communication proteins \\
\hline$\downarrow 5 \cdot 4$ & $\downarrow 1 \cdot 9$ & U37026 & Voltage-gated ion channels \\
\hline$\downarrow 4 \cdot 2$ & $\downarrow 1 \cdot 8$ & X97041 & Voltage-gated ion channels \\
\hline$\downarrow 4 \cdot 0$ & $\downarrow 1 \cdot 9$ & D90219 & Hormones \\
\hline$\downarrow 3 \cdot 0$ & $\downarrow 1 \cdot 3$ & M90661 & Intracellular kinase network members \\
\hline$\downarrow 2 \cdot 9$ & $\downarrow 1 \cdot 5$ & M83676 & $\begin{array}{l}\text { G Proteins; other trafficking and targeting } \\
\text { proteins }\end{array}$ \\
\hline$\downarrow 2 \cdot 8$ & $\downarrow 1 \cdot 1$ & Z17223 & $\begin{array}{l}\text { Other transcription proteins; } \\
\text { telomere-associated proteins }\end{array}$ \\
\hline$\downarrow 2 \cdot 6$ & $\downarrow 1 \cdot 3$ & X14209 & Energy metabolism \\
\hline$\downarrow 2 \cdot 5$ & $\downarrow 1 \cdot 2$ & X05111 & $\begin{array}{l}\text { Cell-cell adhesion receptors; cell surface } \\
\text { antigens }\end{array}$ \\
\hline$\downarrow 2 \cdot 3$ & $\downarrow 1 \cdot 4$ & D10874 & ATPase transporters \\
\hline$\downarrow 2 \cdot 3$ & $\downarrow 1 \cdot 6$ & U52531 & $\begin{array}{l}\text { Growth factor/chemokine/protein kinase } \\
\text { receptors }\end{array}$ \\
\hline$\downarrow 2 \cdot 1$ & $\downarrow 1 \cdot 2$ & X59737 & Energy/nucleotide metabolism \\
\hline$\downarrow 2 \cdot 1$ & $\downarrow 1 \cdot 3$ & D44495 & DNA damage repair proteins and ligases \\
\hline$\downarrow 3 \cdot 1$ & $\downarrow 1 \cdot 6$ & U03763 & Phospholipases and phosphoinositol kinases \\
\hline$\downarrow 2 \cdot 4$ & $\downarrow 1 \cdot 9$ & D10864 & Transcription activators and repressors \\
\hline$\downarrow 2 \cdot 2$ & $\downarrow 1 \cdot 8$ & D63834 & Symporters and antiporters \\
\hline$\downarrow 2 \cdot 1$ & $\downarrow 1 \cdot 8$ & M27882 & Protease inhibitors \\
\hline$\downarrow 2 \cdot 0$ & $\downarrow 1 \cdot 8$ & D16308 & Cyclins; oncogenes and tumor suppressors \\
\hline$\uparrow 3 \cdot 5$ & $\uparrow 1 \cdot 3$ & L19698 & G Proteins \\
\hline$\uparrow 3 \cdot 1$ & $\uparrow 1 \cdot 1$ & U03734 & Metalloproteinases \\
\hline$\uparrow 2 \cdot 9$ & $\uparrow 1 \cdot 3$ & L31884 & Protease inhibitors \\
\hline$\uparrow 2 \cdot 6$ & $\uparrow 1 \cdot 2$ & L20820 & Trafficking and targeting proteins \\
\hline$\uparrow 2 \cdot 4$ & $\uparrow 1 \cdot 1$ & D17614 & Kinase activators and inhibitors \\
\hline$\uparrow 2 \cdot 4$ & $\uparrow 1 \cdot 0$ & M17528 & G Proteins \\
\hline$\downarrow 2 \cdot 6$ & $\downarrow 1 \cdot 4$ & U11760 & Immune system proteins \\
\hline$\downarrow 2 \cdot 3$ & $\downarrow 1 \cdot 9$ & M58593 & Proteosomal proteins \\
\hline$\downarrow 2 \cdot 2$ & $\downarrow 1 \cdot 4$ & AF000423 & Exocytosis/calcium-binding proteins \\
\hline$\downarrow 2 \cdot 1$ & $\downarrow 1 \cdot 5$ & D17711 & $\begin{array}{l}\text { RNA processing, turnover and transport } \\
\text { proteins }\end{array}$ \\
\hline$\uparrow 2 \cdot 6$ & $\uparrow 1 \cdot 3$ & X59601 & Cytoskeleton and motility proteins \\
\hline$\uparrow 2 \cdot 1$ & $\uparrow 1 \cdot 1$ & U40260 & Protease inhibitors \\
\hline
\end{tabular}

$\uparrow 1 \cdot 1$

\section{Initial segment}

Glucose-regulated 78-kDa protein Prohibitin

Neural visinin-like $\mathrm{Ca}^{2+}$-binding protein NVP-3

Cytoplasmic $\beta$-actin

Vasopressin V2 receptor

Dual-specificity MAPKK2

Casein kinase II

Elongation factor 2

Aminopeptidase B

Macrophage migration inhibitory factor Cathepsin L

Cofilin

\section{Caput epididymidis}

Gastric inhibitory polypeptide precursor

Sodium channel SCNB2

Potassium channel Kir6.2

C-type natriuretic peptide precursor

Insulin receptor-related receptor- $\alpha$

rab12, ras related GTPase

Gax, growth-arrest-specific protein

Cytochrome c oxidase, subunit IV

CD2, membrane glycoprotein

Vacuolar ATP synth. 16-kDa proteolipid subunit

erbB4, proto-oncogene

Creatine kinase

Apurinic/apyrimidinic endonuclease

Corpus epididymidis

$\mathrm{Ca}^{++}$-dependent phospholipase A2 precursor

DNA-binding protein inhibitor ID3

Monocarboxylate transporter MCT1

Pancreatic secretory trypsin inhibitor I

precursor (PSTI-I)

G1/S-specific cyclin D2

Ral A; GTP-binding protein

Angiotensin converting enzyme

Tissue inhibitor of metalloproteinase-2

Syntaxin 3

14-3-3 protein theta

GTP-binding protein; G-alpha-i2

\section{Cauda epididymidis}

ATPase, transitional endoplasmic reticulum

Proteasome component C8

SYNAPTOTAGMIN XI

Heterogeneous nuclear ribonucleoprotein $\mathrm{K}$

Plectin

Tissue carboxypeptidase inhibitor

Accession numbers (Acc. numbers) are for the Genbank database. Functional classifications are according to BD Bioscience (Clontech).

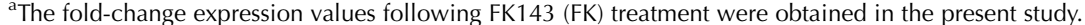

${ }^{\mathrm{b}}$ The fold-changes expression values following PNU157706 treatment (PNU) were obtained from a previous study (Henderson et al. 2004) and are included for comparison purposes. 


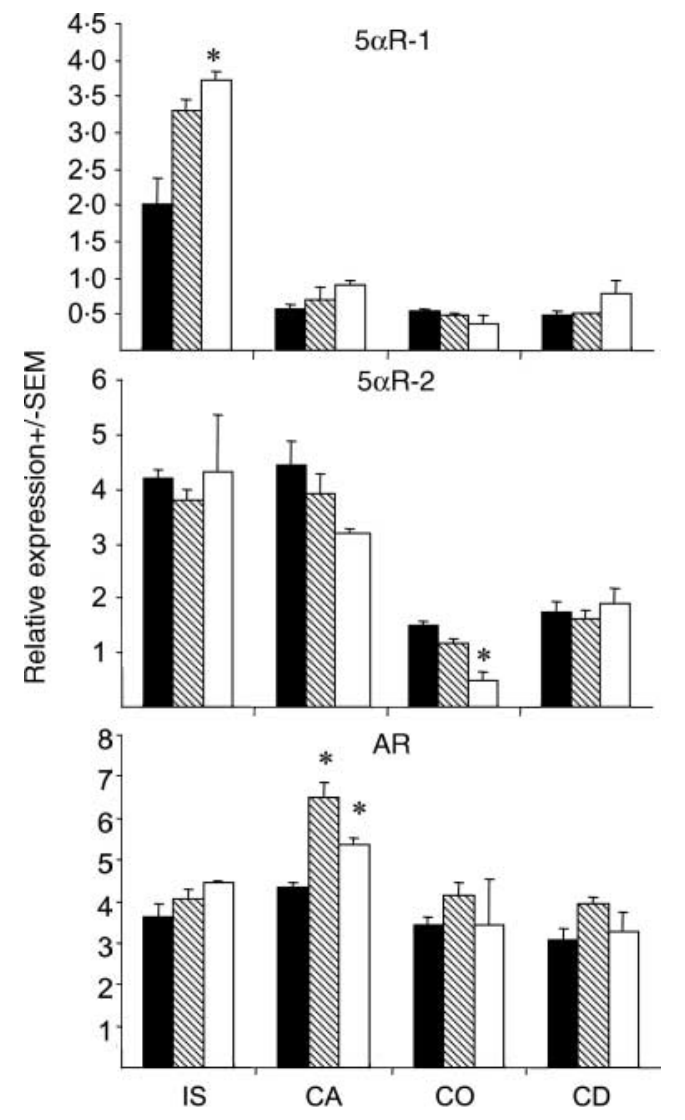

Figure 2 Quantitative real-time RT-PCR analysis of $5 \alpha$-reductase type-1 (5 $\alpha$-R1), $5 \alpha$-reductase type-2 (5 $\alpha$-R2) and androgen receptor (AR) mRNAs in the initial segment (IS), caput (CA), corpus (CO), and cauda (CD) epididymides. All gene expression values are expressed relative to the levels of cyclophilin mRNA and represented as mean \pm S.E.M. RNA extracted from epididymides of vehicle (black bars), PNU15776- (striped bars), and FK143- (white bars) treated rats ( $n=5 /$ group) was used to analyze the effect of $5 \alpha$-reductase inhibitor treatment on mRNA expression profiles. Asterisks $\left(^{*}\right)$ indicate significant differences between the vehicle- and inhibitortreated groups $(P<0 \cdot 05)$.

treatment uniquely in the caput epididymidis. In contrast, the expression of $5 \alpha$-reductase type- 2 remained essentially unaffected by treatment except for an approximate decrease of $66 \%$ in the corpus epididymidis. The corpus epididymidis was also the region where the greatest decrease in $5 \alpha$-reductase type- 2 expression was detected using gene array technology.

\section{Expression of IGF family members in the epididymis}

We examined the steady-state expression of four IGF family members along the epididymis (Fig. 3, black bars). The expression of IGF-I was significantly lower in the caput epididymidis compared with the other regions, where it was expressed at similar levels. The expression of IGF-IR escalated longitudinally, increasing nearly threefold between
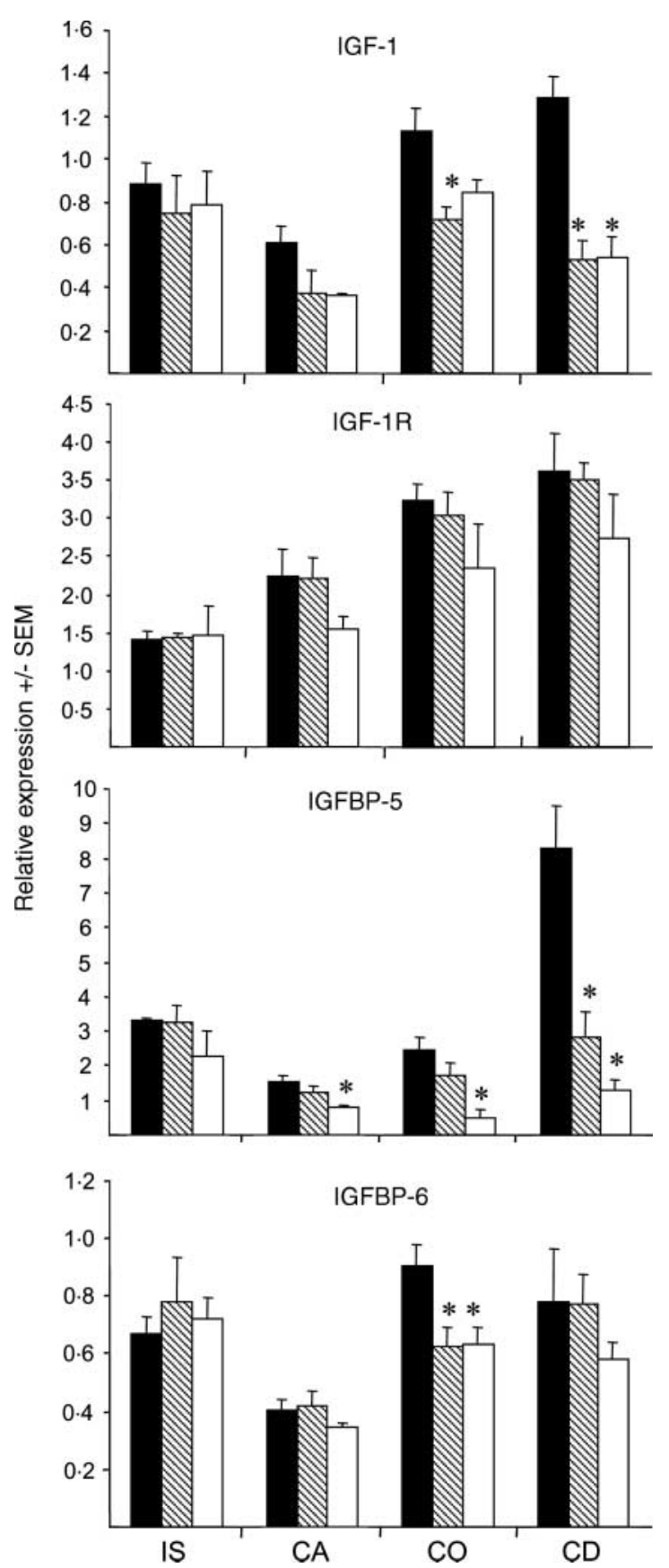

Figure 3 Quantitative real-time RT-PCR analysis of insulin-like growth factor-I (IGF-I), insulin-like growth factor-I receptor (IGF-IR), insulin-like growth factor-binding protein-5 (IGFBP-5), and -6 (IGFBP-6) mRNAs in the initial segment (IS), caput (CA), corpus (CO), and cauda (CD) epididymides. All gene expression values are expressed relative to the levels of cyclophilin mRNA and are represented as mean \pm s.E.M. RNA extracted from epididymides of vehicle (black bars), PNU15776- (striped bars), and FK143- (white bars) treated rats ( $n=5 /$ group) was used to analyze the effect of $5 \alpha$-reductase inhibitor treatment on mRNA expression profiles. Asterisks $(*)$ indicate significant differences between the vehicleand inhibitor-treated groups $(P<0 \cdot 05)$. 
the initial segment and the cauda epididymidis. The expression of IGFBP-5 was also highest in the cauda epididymidis, being on average threefold higher than the other segments. The relative expression values for IGFBP-6 suggest that it is more highly expressed in the epididymis compared with the other IGF family members. However, direct comparisons between different genes cannot be made conclusively, since different target gene primer pairs may not exhibit the same amplification efficiency in PCR experiments. Lastly, the expression profile of IGFBP-6 in the epididymis was very similar to that of IGF-I, such that it was significantly lower in the caput epididymidis compared with the remaining segments.

The effects of dual $5 \alpha$-reductase inhibition on the expression profiles of the four IGF family members are shown in Fig. 3. Again, treatment with two different dual inhibitors had similar effects on the expression profiles of all the IGF family members examined with FK143 having a more pronounced effect. Interestingly, the effects of $5 \alpha$-reductase inhibitor treatment were gene- and regionspecific. The expression of all the four genes remained unaffected by treatment in the initial segment. In the more distal regions of the epididymis, treatment with either inhibitor caused a general decrease in the expression of most IGF family members examined. More specifically, the expression of IGF-I and IGFBP-5 was the most affected by treatment, maximally decreasing by 60 and $84 \%$ in the cauda epididymidis, respectively. Decreased expression was also observed for IGFBP-6, reaching significance in the corpus epididymidis. These changes in gene expression reflect what was found using gene array technology in the present study.

\section{Expression of FGF family members in the epididymis}

The steady-state expression profiles for the ligand, fibroblast growth factor-10 (FGF-10), and the receptor, fibroblast growth factor receptor-2 (FGFR-2) were examined in the epididymis (Fig. 4, black bars). The steady-state expression of FGF-10 was significantly lower in the caput epididymidis compared with all other regions. The steady-state expression of FGFR-2 was significantly higher in the cauda epididymidis compared with more proximal regions. The relative expression values for FGFR-2 suggest that it is quite highly expressed in the epididymis compared with the other genes analyzed.

The effects of PNU157706 and FK143 treatment on the epididymal expression of FGF-10 and FGFR-2 expression were analyzed (Fig. 4). FGF-10 gene expression was significantly affected by both the inhibitor treatments; it decreased maximally with FK143 treatment in the corpus and cauda epididymides approximately by 45 and $31 \%$ respectively. Inhibitor treatments did not result in a significant decrease in FGFR-2 expression.

\section{Expression of TGF family members in the epididymis}

The steady-state expression profiles for the ligand, transforming growth factor- $\beta 1$ (TGF- $\beta 1$ ), and the receptor, transforming

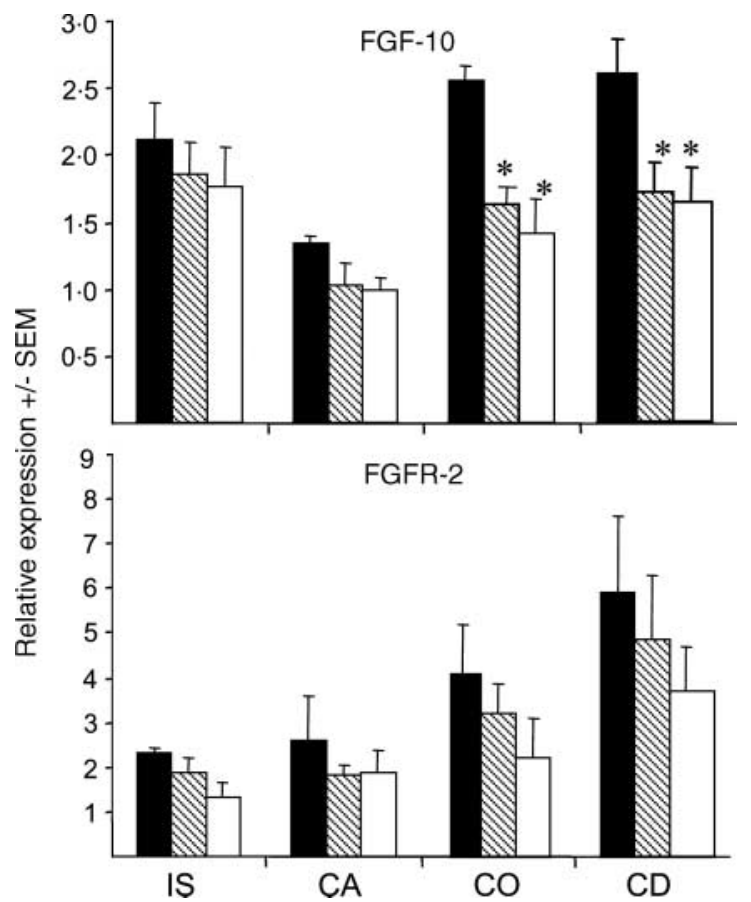

Figure 4 Quantitative real-time RT-PCR analysis of fibroblast growth factor-10 (FGF-10) and fibroblast growth factor receptor-2 (FGFR-2) mRNAs in the initial segment (IS), caput (CA), corpus $(\mathrm{CO})$, and cauda (CD) epididymides. All gene expression values are expressed relative to the levels of cyclophilin mRNA and are represented as mean \pm s.E.M. RNA extracted from epididymides of vehicle (black bars), PNU15776- (striped bars) and FK143- (white bars) treated rats ( $n=5 /$ group) was used to analyze the effect of $5 \alpha$-reductase inhibitor treatment on mRNA expression profiles. Asterisks $(*)$ indicate significant differences between the vehicleand inhibitor-treated groups $(P<0 \cdot 05)$.

growth factor- $\beta 1$ receptor (TGF- $\beta 1 \mathrm{R}$ ), were examined in the epididymis (Fig. 5 , black bars). The expression of TGF- $\beta 1$ was relatively constant in the initial segment, caput, and corpus epididymides, and peaked in the cauda epididymidis nearly to double the levels in the proximal regions. In contrast, TGF- $\beta 1 \mathrm{R}$ was expressed in the initial segment and corpus epididymidis at approximately twice the levels in the caput and cauda epididymides. The relative expression values for TGF- $\beta 1 \mathrm{R}$ were the highest of all the genes examined.

The effects of dual $5 \alpha$-reductase inhibitor treatment on epididymal TGF- $\beta 1$ and TGF- $\beta 1 \mathrm{R}$ expression were analyzed (Fig. 5). The only significant effects of $5 \alpha$-reductase inhibitor treatment were on the expression of TGF- $\beta 1$ in the caput epididymidis, which nearly doubled following treatment, and TGF- $\beta 1 R$ in the cauda epididymidis, which decreased.

\section{Expression of VEGF family members in the epididymis}

The steady-state expression profiles for the ligand, vascular endothelial growth factor (VEGF), and the receptor, vascular endothelial growth factor receptor-2 (VEGFR-2), were examined in the epididymis (Fig. 6, black bars). Both the 


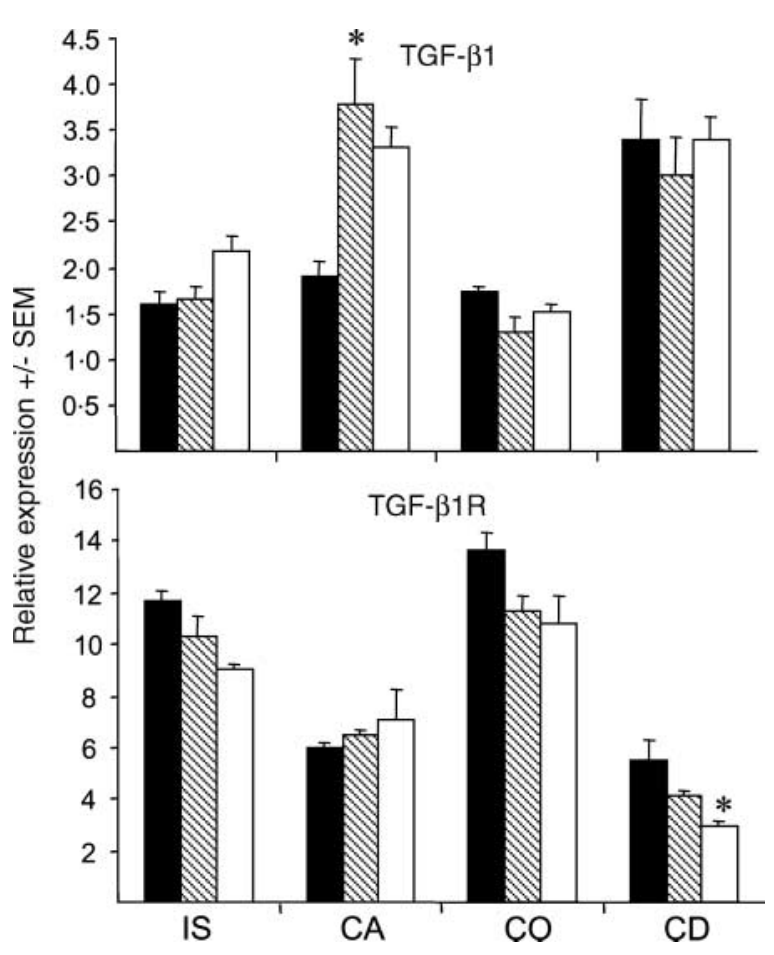

Figure 5 Quantitative real-time RT-PCR analysis of transforming growth factor- $\beta 1$ (TGF- $\beta 1$ ) and transforming growth factor- $\beta 1$ receptor (TGF- $\beta 1 R$ ) mRNAs in the initial segment (IS), caput (CA), corpus (CO), and cauda (CD) epididymides. All gene expression values are expressed relative to the levels of cyclophilin mRNA and are represented as mean \pm s.E.M. RNA extracted from epididymides of vehicle (black bars), PNU15776- (striped bars) and FK143- (white bars) treated rats ( $n=5 /$ group) was used to analyze the effect of $5 \alpha$-reductase inhibitor treatment on mRNA expression profiles. Asterisks $(*)$ indicate significant differences between the vehicleand inhibitor-treated groups $(P<0 \cdot 05)$.

genes were most highly expressed in the initial segment. VEGF expression was lowest in the caput epididymidis and increased slightly towards the cauda epididymidis. VEGFR-2 was expressed in the caput, corpus, and cauda epididymides at approximately $63-74 \%$ of the initial segment expression level.

The effects of dual $5 \alpha$-reductase inhibitor treatment on epididymal VEGF and VEGFR-2 expression were analyzed (Fig. 6). In contrast to all the other growth factors analyzed, there were no significant effects of treatment with either inhibitor in any region of the epididymis.

\section{Discussion}

Previously, we demonstrated that the dual $5 \alpha$-reductase inhibitor PNU157706 inhibited epididymal $5 \alpha$-reductase activity in vitro and had extensive effects on epididymal gene expression in vivo (Henderson et al. 2004). In the present study, we confirmed that a second compound, FK143, is a noncompetitive inhibitor of nuclear and microsomal epididymal

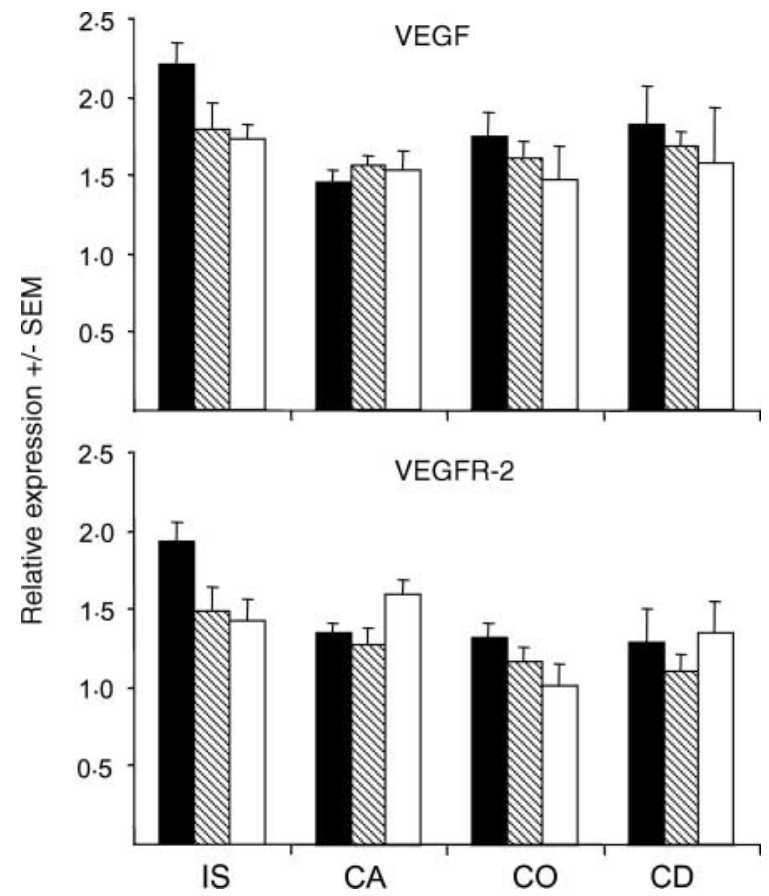

Figure 6 Quantitative real-time RT-PCR analysis of vascular endothelial growth factor (VEGF) and vascular endothelial growth factor receptor-2 (VEGFR-2) mRNAs in the initial segment (IS), caput (CA), corpus (CO), and cauda (CD) epididymides. All gene expression values are expressed relative to the levels of cyclophilin mRNA and are represented as mean \pm S.E.M. RNA extracted from epididymides of vehicle (black bars), PNU15776- (striped bars) and FK143- (white bars) treated rats ( $n=5 /$ group) was used to analyze the effect of $5 \alpha$-reductase inhibitor treatment on mRNA expression profiles. Asterisks $(*)$ indicate significant differences between the vehicle- and inhibitor-treated groups $(P<0 \cdot 05)$.

$5 \alpha$-reductase activity in vitro. Furthermore, it was found that treatment with FK143 elicited changes in epididymal gene expression that were analogous to those observed with PNU157706, as evidenced by gene array studies. These corroborating findings clearly indicate that the observed changes in gene expression are due to the common effect of both the compounds on the inhibition of DHT formation, as opposed to a mechanism different than $5 \alpha$-reductase inhibition.

Recently, we showed that the treatment of male rats with PNU157706 affects epididymal sperm maturation as evidenced by changes in epididymal sperm morphology, motility, and fertilizing ability (Henderson \& Robaire 2005). It is highly likely that the effects of dual $5 \alpha$-reductase inhibition on epididymal sperm maturation are linked to the effects of inhibitor treatment on the expression of genes that can be functionally categorized according to important epididymal epithelial processes (i.e. processes that contribute to the formation of the epididymal luminal environment). What remains unclear is the identity of region-specific signaling/regulatory molecules and pathways involved in mediating the upstream and/or downstream effects of DHT on epididymal gene expression and function. 
In the present study, we focused our gene expression analyses specifically on potential signaling molecules in the epididymis, including both $5 \alpha$-reductase isozymes and the androgen receptor, as well as several components of different growth factor systems. Moreover, we determined whether the expression of these genes was dependent on DHT by assessing the effects of dual $5 \alpha$-reductase inhibition. For the most part, these genes have not been extensively characterized in the epididymis with the exception of the $5 \alpha$-reductase isozymes and the androgen receptor. Thus, this is the first study demonstrating the differential distribution and regulation of many of these genes.

\section{Expression of $5 \alpha$-reductases and the androgen receptor in the epididymis}

The expression of both $5 \alpha$-reductase isozymes has been previously characterized in the epididymis (Viger \& Robaire 1991, 1994, 1996). Moreover, the region-specific epididymal expression profiles of these genes show different patterns during development and aging, and respond differently to efferent duct ligation and bilateral orchidectomy (Viger \& Robaire 1991, 1992, 1994, 1995, 1996). However, this is the first study to employ $5 \alpha$-reductase inhibitors to specifically examine the DHT regulation of the expression of these genes in the epididymis. Our results are consistent with the differential regulation of the $5 \alpha$-reductase isozymes in this tissue. Type-1 $5 \alpha$-reductase expression was specifically increased in the initial segment following inhibitor treatment, suggesting a negative-feedback mechanism of regulation by DHT in this region. In contrast, the expression of $5 \alpha$-reductase type- 2 was affected only in a limited manner by treatment in the corpus epididymidis. Interestingly, androgen status has been shown to regulate the expression of both $5 \alpha$-reductase isozymes differently in different tissues. For example, in the rat brain, type-1 $5 \alpha$-reductase expression increases following castration, and androgen replacement with DHT reverses this increase to a larger extent than testosterone replacement (Torres \& Ortega 2003a). In contrast, $5 \alpha$-reductase type- 2 expression falls in the rat prefrontal cortex after castration and increases dramatically with testosterone replacement compared with DHT replacement (Torres \& Ortega 2003a). In fact, the exogenous administration of testosterone, and to a lesser extent DHT, increased type-2 $5 \alpha$-reductase expression even in intact animals (Torres \& Ortega 2003a). Testosterone has also been shown to control the expression of $5 \alpha$-reductase type- 2 in the rat prostate, while both testosterone and DHT positively regulate $5 \alpha$-reductase type- 1 expression in the rat liver (Torres \& Ortega 2003b, Torres et al. 2003). The differential regulation of both $5 \alpha$-reductase isozymes suggests that they play physiologically distinct roles in different tissues. Further studies are needed to fully characterize these distinct roles.

As expected, the present real-time PCR expression results were analogous to what has been previously described for the androgen receptor in the epididymis; androgen receptor gene expression is relatively constant throughout the tissue with levels slightly higher in the caput epididymidis compared with those in the cauda epididymidis (Pujol \& Bayard 1979, Tezon \& Blaquier 1983, Viger \& Robaire 1995). Studies have also shown that circulating androgens regulate the expression of the androgen receptor in the epididymis (Pujol \& Bayard 1979, Tezon \& Blaquier 1983); however, as with most of the genes previously examined in the epididymis, no differentiation was made between total androgens (i.e. testosterone plus DHT) and DHT alone. Our results suggest that androgen receptor expression is regulated by DHT specifically in the caput epididymidis.

\section{Growth factor systems in the epididymis}

Studies using prostate cell lines have provided evidence to support androgen receptor cross-talk with growth factor signaling pathways, resulting in both enhanced androgen responses and receptor ligand-independent activation and modulation of androgen receptor transactivation (Culig et al. 1994, 1995, Orio et al. 2002, Huang et al. 2004). Thus, it seems plausible that similar interactions occur in other reproductive tissues, including the epididymis; however, this remains to be examined. The characterization of recently established epididymal cell lines should facilitate further investigation into the interactions between androgen and growth factor signaling pathways in the epididymis (Kirchhoff et al. 2004, Tabuchi et al. 2005).

A physiological role for IGF-I in the regulation of epididymal functions was hypothesized over 10 years ago due to the varied immunohistochemical localization of IGF-I protein in the rat epididymis (Leheup \& Grignon 1993). IGF-IR protein and mRNA have also been localized to the epididymis (Antich et al. 1995, Baker et al. 1996). Adult mice with a homozygous null mutation of the IGF-I gene are infertile dwarfs with reduced testosterone production, and consequently reduced spermatogenesis and reproductive organ size (Baker et al. 1996). Interestingly, the epididymal phenotype of IGF-I null mice is more severe in the distal regions of the epididymis with greater reductions in weight and decreased coiling. In the present study, the expression of IGF-I and IGF-IR was found to be highest in the distal epididymal regions. These results are consistent with a role for IGF signaling in the distal regions of the epididymis (corpus and cauda epididymides) and this conclusion is corroborated by results from the present study demonstrating the unique effects of $5 \alpha$-reductase inhibitor treatment on the expression of IGF-I and possibly IGF-IR, predominantly in the corpus and cauda epididymides.

The IGF network also includes numerous IGF-binding proteins that modulate the bioavailability and cellular functions of IGFs (Jones \& Clemmons 1995). We analyzed the epididymal expression of two high-affinity binding proteins, IGFBP-5, and IGFBP-6. Again, these genes were more highly expressed in the distal regions of the epididymis and mainly affected by $5 \alpha$-reductase inhibitor treatment in these regions. IGFBP-5 expression was particularly affected by treatment, decreasing dramatically in the cauda epididymidis. 
Various FGF receptors have been characterized exclusively in principal cells of the initial segment of the rat epididymis (Kirby et al. 2003). Our results also indicate a role for FGF signaling in the distal part of the epididymis, since the highest expression levels for FGF-10 and its receptor FGFR-2 were in the corpus and cauda epididymides. Furthermore, the effects of $5 \alpha$-reductase inhibitor treatment were most pronounced in these regions.

Differential expression profiles for TGF- $\beta$ isoforms (TGF- $\beta 1$, TGF- $\beta 2$, and TGF- $\beta 3$ ) have previously been characterized in the rat epididymis by northern blot (Desai et al. 1998, Desai \& Kondaiah 2000). In these studies, substantial TGF- $\beta 1$ expression was observed compared with other isoforms; TGF- $\beta 1$ expression was upregulated in the caput, corpus, and cauda epididymides following total androgen ablation by orchidectomy. In the present study, we also observed the upregulation of TGF- $\beta 1$ expression most predominantly in the caput epididymidis with no changes in the distal regions. Taken together, these data suggest that TGF- $\beta 1$ is uniquely regulated by different androgens in the epididymis; our results indicate that there is a DHT-dependent repression of TGF- $\beta 1$ in the proximal epididymis, while castration-induced increases in TGF- $\beta 1$ expression in the corpus and cauda epididymides, indicating a specific role for total androgens or testosterone in these regions. Roles for the TGF- $\beta$ family have also been implicated in other DHT-dependent reproductive tissues, such as the seminal vesicle and ventral prostate (Tanji et al. 1994, Timme et al. 1994). TGFß-1 in particular was also shown to be repressed by androgens in the regressing rat ventral prostate (Kyprianou \& Isaacs 1989), similar to what was observed in the epididymis, further supporting a role for androgens in regulating the expression of this gene.

To the best of our knowledge, this is the first study demonstrating the differential distribution of any TGF- $\beta$ receptor mRNA in the epididymis. The presence of both the ligand and the receptor strongly supports the TGF- $\beta$ system in the epididymis; however, DHTonly appears to regulate this system at the level of the ligand.

Vascular endothelial growth factor (VEGF) protein was shown to be localized in the rat epididymal epithelium in a region- and cell-specific pattern (Zhang et al. 2004); for example, clear cells in the caput, corpus, and cauda epididymides were immunoreactive for VEGF. In humans, VEGF protein has been localized to peritubular and basal cells of the epididymal duct and VEGFR-2 protein to vascular endothelial cells of the epididymis (Ergun et al. 1998). Interestingly, the overexpression of VEGF in the testis and epididymis of transgenic mice causes infertility (Korpelainen et al. 1998). These findings suggest a role for VEGF in the epididymis, likely as a paracrine regulator of the epididymal vasculature as opposed to the epididymal epithelium. In the present study, we confirmed the differential distribution of both the VEGF and VEGFR-2 mRNAs in the rat epididymis. Interestingly, unlike the other growth factor families examined, $5 \alpha$-reductase inhibitor treatment had no significant effect on the expression of VEGF or VEGFR-2, reflecting a lack of DHT regulation of this growth factor system in the epididymis. This may be due to the predominant vascular localization as opposed to epithelial localization of this system in the epididymis, which is unique from other growth factor signaling systems.

It is of interest to note that the testis has been shown to produce and secrete many different growth factors, including components of the IGF, TGF, EGF, FGF, PDGF, and NGF systems (reviewed in Gnessi et al. 1997). It has been well established that the epididymis, in particular the initial segment, is dependent on the testicular input of factors, other than androgens, directly to the epididymal lumen (Robaire et al. 1981, Nicander et al. 1983, Turner \& Riley 1999); depriving the epididymis of these testicular factors (i.e. via efferent duct ligation) has well-documented effects on gene expression in the initial segment (reviewed in Hinton et al. 1998). This type of paracrine regulatory mechanism has been coined 'lumicrine' regulation, since it occurs via a ductal system (Hinton et al. 1998). Thus, it is plausible that growth factors originating in the testis can act as 'lumicrine' regulators of the epididymis by acting on their corresponding receptors present in the epididymal epithelium. Similarly, it is also likely that the growth factors secreted in one region of the epididymis can act on the receptors located in the same or more distal regions of the epididymis representing autocrine or paracrine regulatory mechanisms.

In summary, the collective findings of the present study suggest that sex steroid and growth factor signaling become dysregulated following $5 \alpha$-reductase inhibition, leading to altered epididymal gene expression and function. Furthermore, the results of this study support the involvement of differential signaling mechanisms in regulating and/or mediating the actions of androgens (predominantly DHT) in the different regions of the epididymis. This regulatory diversity is likely to be important in controlling region-specific sperm-related functions.

\section{Acknowledgements}

We thank Dr T Zaccheo from Pharmacia and Upjohn (presently Pfizer) and Dr Yasutaka Shigi from Fujisawa Pharmaceutical Co. for the generous gifts of PNU157706 and FK143 respectively. Melanie Deslauriers is gratefully acknowledged for her assistance in developing the real-time PCR assays for the $5 \alpha$-reductase isozymes.

\section{Funding}

$\mathrm{NAH}$ is a recipient of a studentship from the Canadian Institutes of Health Research. These studies were supported by a grant from the Canadian Institutes of Health Research. The authors declare that there is no conflict of interest that would prejudice the impartiality of this scientific work. 


\section{References}

Antich M, Fabian E, Sarquella J \& Bassas L 1995 Effect of testicular damage induced by cryptorchidism on insulin-like growth factor I receptors in rat Sertoli cells. Journal of Reproduction and Fertility 104 267-275.

Baker J, Hardy MP, Zhou J, Bondy C, Lupu F, Bellve AR \& Efstratiadis A 1996 Effects of an Igf1 gene null mutation on mouse reproduction. Molecular Endocrinology 10 903-918.

Blaquier JA, Burgos MH \& Cameo MS 1972 Role of androgens in maturation of epididymal spermatozoa in guinea-pig. Endocrinology 90 839-842.

Bustin SA 2002 Quantification of mRNA using real-time reverse transcription PCR (RT-PCR): trends and problems. Journal of Molecular Endocrinology $2923-39$.

Cornwall GA, Lareyre JJ, Matusik RJ, Hinton BT \& Orgebin-Crist MC 2002 Gene expression and epididymal function. In The Epididymis: From Molecules to Clinical Practice, pp 169-199. Eds B Robaire \& BT Hinton. New York: Kluwer Academic/Plenum Publishers.

Culig Z, Hobisch A, Cronauer MV, Radmayr C, Trapman J, Hittmair A, Bartsch G \& Klocker H 1994 Androgen receptor activation in prostatic tumor cell lines by insulin-like growth factor-I, keratinocyte growth factor, and epidermal growth factor. Cancer Research 54 5474-5478.

Culig Z, Hobisch A, Cronauer MV, Hittmair A, Radmayr C, Bartsch G \& Klocker H 1995 Activation of the androgen receptor by polypeptide growth factors and cellular regulators. World Journal of Urology 13 285-289.

Cupp AS, Kim G \& Skinner MK 1999 Expression and action of transforming growth factor beta (TGFbeta1, TGFbeta2, and TGFbeta3) during embryonic rat testis development. Biology of Reproduction 60 1304-1313.

Desai KV \& Kondaiah P 2000 Androgen ablation results in differential regulation of transforming growth factor-beta isoforms in rat male accessory sex organs and epididymis. Journal of Molecular Endocrinology 24 253-260.

Desai KV, Flanders KC \& Kondaiah P 1998 Expression of transforming growth factor-beta isoforms in the rat male accessory sex organs and epididymis. Cell and Tissue Research 294 271-277.

Ergun S, Luttmer W, Fiedler W \& Holstein AF 1998 Functional expression and localization of vascular endothelial growth factor and its receptors in the human epididymis. Biology of Reproduction 58 160-168.

Ezer N \& Robaire B 2003 Gene expression is differentially regulated in the epididymis after orchidectomy. Endocrinology 144 977-988.

Gloyna RE \& Wilson JD 1969 A comparitive study of the conversion of testosterone to $17 \beta$-hydroxy- $5 \alpha$-androstan-3-one (dihydrotestosterone) by rat prostate and epididymis. Journal of Clinical Endocrinology and Metabolism 29 970-977.

Gnessi L, Fabbri A \& Spera G 1997 Gonadal peptides as mediators of development and functional control of the testis: an integrated system with hormones and local environment. Endocrine Reviews 18 541-609.

Gomez R, Simon C, Remohi J \& Pellicer A 2003 Administration of moderate and high doses of gonadotropins to female rats increases ovarian vascular endothelial growth factor (VEGF) and VEGF receptor-2 expression that is associated to vascular hyperpermeability. Biology of Reproduction $\mathbf{6 8}$ 2164-2171.

Hanawa H, Abe S, Hayashi M, Yoshida T, Yoshida K, Shiono T, Fuse K, Ito M, Tachikawa H, Kashimura Tet al. 2002 Time course of gene expression in rat experimental autoimmune myocarditis. Clinical Science 103 623-632.

Henderson NA \& Robaire B 2005 Effects of PNU157706, a dual 5alphareductase inhibitor, on rat epididymal sperm maturation and fertility. Biology of Reproduction 72 436-443.

Henderson NA, Cooke GM \& Robaire B 2004 Effects of PNU157706, a dual 5alpha-reductase inhibitor, on gene expression in the rat epididymis. Journal of Endocrinology 181 245-261.

Herwig R, Aanstad P, Clark M \& Lehrach H 2001 Statistical evaluation of differential expression on cDNA nylon arrays with replicated experiments. Nucleic Acids Research 29 e117.

Hinton BT, Lan ZJ, Rudolph DB, Labus JC \& Lye RJ 1998 Testicular regulation of epididymal gene expression. Journal of Reproduction and Fertility. Supplement $\mathbf{5 3}$ 47-57.
Hirosumi J, Nakayama O, Fagan T, Sawada K, Chida N, Inami M, Takahashi S, Kojo H, Notsu Y \& Okuhara M 1995a FK143, a novel nonsteroidal inhibitor of steroid 5 alpha-reductase: (1) in vitro effects on human and animal prostatic enzymes. Journal of Steroid Biochemistry and Molecular Biology 52 357-363.

Hirosumi J, Nakayama O, Chida N, Inami M, Fagan T, Sawada K, Shigematsu S, Kojo H, Notsu Y \& Okuhara M 1995b FK143, a novel nonsteroidal inhibitor of steroid 5 alpha-reductase: (2) in vivo effects on rat and dog prostates. Journal of Steroid Biochemistry and Molecular Biology 52 365-373.

Huang D, Liu X, Plymate SR, Idowu M, Grimes M, Best AM, McKinney JL \& Ware JL 2004 Proteomic identification of 14-3-3 sigma as a common component of the androgen receptor and the epidermal growth factor receptor signaling pathways of the human prostate epithelial cell line M12. Oncogene 23 6881-6889.

Jervis KM \& Robaire B 2001 Dynamic changes in gene expression along the rat epididymis. Biology of Reproduction 65 696-703.

Jervis KM \& Robaire B 2002 Changes in gene expression during aging in the Brown Norway rat epididymis. Experimental Gerontology 37 897-906.

Jervis KM \& Robaire B 2003 Effects of caloric restriction on gene expression along the epididymis of the Brown Norway rat during aging. Experimental Gerontology 38 549-560.

Jervis KM \& Robaire B 2004 The effects of long-term vitamin E treatment on gene expression and oxidative stress damage in the aging Brown Norway rat epididymis. Biology of Reproduction 71 1088-1095.

Jones JI \& Clemmons DR 1995 Insulin-like growth factors and their binding proteins: biological actions. Endocrine Reviews 16 3-34.

Kirby JL, Yang L, Labus JC \& Hinton BT 2003 Characterization of fibroblast growth factor receptors expressed in principal cells in the initial segment of the rat epididymis. Biology of Reproduction 68 2314-2321.

Kirchhoff C, Araki Y, Huhtaniemi I, Matusik RJ, Osterhoff C, Poutanen M, Samalecos A, Sipila P, Suzuki K \& Orgebin-Crist MC 2004 Immortalization by large T-antigen of the adult epididymal duct epithelium. Molecular and Cellular Endocrinology 216 83-94.

Korpelainen EI, Karkkainen MJ, Tenhunen A, Lakso M, Rauvala H, Vierula M, Parvinen M \& Alitalo K 1998 Overexpression of VEGF in testis and epididymis causes infertility in transgenic mice: evidence for nonendothelial targets for VEGF. Journal of Cell Biology 143 1705-1712.

Kyprianou N \& Isaacs JT 1989 Expression of transforming growth factor-beta in the rat ventral prostate during castration-induced programmed cell death. Molecular Endocrinology 3 1515-1522.

Lee MLT, Kuo FC, Whitmore GA \& Sklar J 2000 Importance of replication in microarray gene expression studies: statistical methods and evidence from repetitive cDNA hybridizations. PNAS 97 9834-9839.

Leheup BP \& Grignon G 1993 Immunohistochemical localization of insulinlike growth factor I (IGF-I) in the rat epididymis. Journal of Andrology 14 159-163.

Lekanne Deprez RH, Fijnvandraat AC, Ruijter JM \& Moorman AF 2002 Sensitivity and accuracy of quantitative real-time polymerase chain reaction using SYBR green I depends on cDNA synthesis conditions. Analytical Biochemistry 307 63-69.

Nicander L, Osman DI, Ploen L, Bugge HP \& Kvisgaard KN 1983 Early effects of efferent ductile ligation on the proximal segment of the rat epididymis. International Journal of Andrology 6 91-102.

Orgebin-Crist MC 1967 Sperm maturation in rabbit epididymis. Nature 216 816-818.

Orgebin-Crist MC \& Tichenor PL 1973 Effect of testosterone on sperm maturation in vitro. Nature 245 328-329.

Orgebin-Crist MC, Jahad N \& Hoffman LH 1976 Effects of testosterone, 5-alpha-dihydrotestosterone, 3-alpha-androstanediol, and 3-beta-androstanediol on maturation of rabbit epididymal spermatozoa in organ-culture. Cell and Tissue Research 167 515-525.

Orio F Jr, Terouanne B, Georget V, Lumbroso S, Avances C, Siatka C \& Sultan C 2002 Potential action of IGF-1 and EGF on androgen receptor nuclear transfer and transactivation in normal and cancer human prostate cell lines. Molecular and Cellular Endocrinology 198 105-114.

Palladino MA \& Hinton BT 1994 Expression of multiple gamma-glutamyl transpeptidase messenger ribonucleic acid transcripts in the adult rat epididymis is differentially regulated by androgens and testicular factors in a region-specific manner. Endocrinology 135 1146-1156. 
Pujol A \& Bayard F 1979 Androgen receptors in the rat epididymis and their hormonal control. Journal of Reproduction and Fertility 56 217-222.

Robaire B \& Hinton BT 2002 (eds) The Epididymis: From Molecules to Clinical Practice. New York: Kluwer Academic/Plenum Publishers.

Robaire B, Scheer H \& Hachey C 1981 Regulation of epididymal steroid metabolizing enzymes. In Bioregulators of Reproduction, pp 487-498. Eds G Jagieuo \& HJ Vogel. New York: Academic Press.

di Salle E, Giudici D, Radice A, Zaccheo T, Ornati G, Nesi M, Panzeri A, Delos S \& Martin PM 1998 PNU157706, a novel dual type I and II 5 alphareductase inhibitor. Journal of Steroid Biochemistry and Molecular Biology 64 179-186.

Tabuchi Y, Toyama Y, Toshimori K, Komiyama M, Mori C \& Kondo T 2005 Functional characterization of a conditionally immortalized mouse epididymis caput epithelial cell line MEPC5 using temperature-sensitive simian virus 40 large T-antigen. Biochemical and Biophysical Research Communications 329 812-823.

Tanji N, Tsuji M, Terada N, Takeuchi M \& Cunha GR 1994 Inhibitory effects of transforming growth factor-beta 1 on androgen-induced development of neonatal mouse seminal vesicles in vitro. Endocrinology 134 1155-1162.

Tezon JG \& Blaquier JA 1983 Androgens control androgen-binding sites in rat epididymis. Endocrinology 113 1025-1030.

Timme TL, Truong LD, Merz VW, Krebs T, Kadmon D, Flanders KC, Park SH \& Thompson TC 1994 Mesenchymal-epithelial interactions and transforming growth factor-beta expression during mouse prostate morphogenesis. Endocrinology 134 1039-1045.

Tindall DJ, Nayfeh SN \& French FS 1972 Androgen uptake and binding in rat epididymal nuclei, in vivo. Biochemical and Biophysical Research Communications 49 1391-1397.

Torres JM \& Ortega E 2003a Differential regulation of steroid 5alphareductase isozymes expression by androgens in the adult rat brain. FASEB Journal 17 1428-1433.

Torres JM \& Ortega E 2003b Precise quantitation of 5alpha-reductase type 1 mRNA by RT-PCR in rat liver and its positive regulation by testosterone and dihydrotestosterone. Biochemical and Biophysical Research Communications 308 469-473.

Torres JM, Gomez-Capilla JA, Ruiz E \& Ortega E 2003 Semiquantitative RT-PCR method coupled to capillary electrophoresis to study 5alphareductase mRNA isozymes in rat ventral prostate in different androgen status. Molecular and Cellular Biochemistry 250 125-130.
Turner TT \& Riley TA 1999 p53 independent, region-specific epithelial apoptosis is induced in the rat epididymis by deprivation of luminal factors. Molecular Reproduction and Development 53 188-197.

Turner TT, Jones CE, Howards SS, Ewing LL, Zegeye B \& Gunsalus GL 1984 On the androgen microenvironment of maturing spermatozoa. Endocrinology 115 1925-1932.

Turner KJ, McIntyre BS, Phillips SL, Barlow NJ, Bowman CJ \& Foster PM 2003 Altered gene expression during rat Wolffian duct development in response to in utero exposure to the antiandrogen linuron. Toxicological Sciences 74 114-128.

Vickers MH, Casey PJ, Champion ZJ, Gravance CG \& Breier BH 1999 IGF-I treatment increases motility and improves morphology of immature spermatozoa in the GH-deficient dwarf $(d w / d w)$ rat. Growth Hormone and IGF Research 9 236-240.

Viger RS \& Robaire B 1991 Differential regulation of steady-state 4-ene steroid 5 alpha-reductase messenger ribonucleic acid levels along the rat epididymis. Endocrinology 128 2407-2414.

Viger RS \& Robaire B 1992 Expression of 4-ene steroid 5 alpha-reductase messenger ribonucleic acid in the rat epididymis during postnatal development. Endocrinology 131 1534-1540.

Viger RS \& Robaire B 1994 Immunocytochemical localization of 4-ene steroid 5 alpha-reductase type 1 along the rat epididymis during postnatal development. Endocrinology 134 2298-2306.

Viger RS \& Robaire B 1995 Gene expression in the aging brown Norway rat epididymis. Journal of Andrology 16 108-117.

Viger RS \& Robaire B 1996 The mRNAs for the steroid 5 alpha-reductase isozymes, types 1 and 2 , are differentially regulated in the rat epididymis. Journal of Andrology 17 27-34.

Wilkinson GN 1961 Statistical estimations in enzyme kinetics. Biochemical Journal 80 324-332.

Zhang QY, Qiu SD \& Ge L 2004 Studies on expression and location of VEGF protein in rat testis and epididymis. Shi Yan Sheng Wu Xие Bao 37 1-8.

Received 13 March 2006

Received in final form 28 May 2006

Accepted 20 June 2006

Made available online as an Accepted Preprint

17 July 2006 